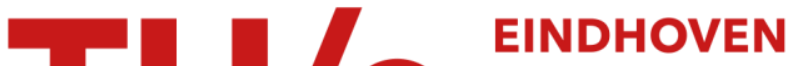 UNIVERSITY OF TECHNOLOGY
}

\section{Simple technologies for fabrication of low-loss silica waveguides}

\section{Citation for published version (APA):}

Lai, Q., Gu, J. S., Smit, M. K., Schmid, J., \& Melchior, H. (1992). Simple technologies for fabrication of low-loss silica waveguides. Electronics Letters, 28(11), 1000-1001.

\section{Document status and date:}

Published: 01/01/1992

\section{Document Version:}

Publisher's PDF, also known as Version of Record (includes final page, issue and volume numbers)

\section{Please check the document version of this publication:}

- A submitted manuscript is the version of the article upon submission and before peer-review. There can be important differences between the submitted version and the official published version of record. People interested in the research are advised to contact the author for the final version of the publication, or visit the $\mathrm{DOI}$ to the publisher's website.

- The final author version and the galley proof are versions of the publication after peer review.

- The final published version features the final layout of the paper including the volume, issue and page numbers.

Link to publication

\section{General rights}

Copyright and moral rights for the publications made accessible in the public portal are retained by the authors and/or other copyright owners and it is a condition of accessing publications that users recognise and abide by the legal requirements associated with these rights.

- Users may download and print one copy of any publication from the public portal for the purpose of private study or research.

- You may not further distribute the material or use it for any profit-making activity or commercial gain

- You may freely distribute the URL identifying the publication in the public portal.

If the publication is distributed under the terms of Article 25fa of the Dutch Copyright Act, indicated by the "Taverne" license above, please follow below link for the End User Agreement:

www.tue.nl/taverne

Take down policy

If you believe that this document breaches copyright please contact us at:

openaccess@tue.nl

providing details and we will investigate your claim. 
SIMPLE TECHNOLOGIES FOR FABRICATION OF LOW-LOSS SILICA WAVEGUIDES

Q. Lai, J. S. Gu, M. K. Smit, J. Schmid and H. Melchior

Indexing terms: Optical waveguides, Glass, Integrated optics

A simple and reproducible technology is developed for the fabrication of low-loss silica waveguides on silicon substrates. The guiding layer is formed by changing the $\mathrm{Si}-\mathrm{O}$ ratio composition of the $\mathrm{SiO}$ layer. The waveguides can be made to have a good match to either optical fibres or guided-wave devices in III-V compound semiconductors.

Introduction: Silica-based optical waveguides have received much attention in recent years in guided-wave optical circuits owing to the advantages of low-cost, low propagation loss, hybrid optical packaging and good match to optical fibres [1-2]. A variety of circuits and components based on silica waveguides have been developed by AT\&T Bell Laboratories and NTT Opto-Electronics Laboratories [3-7]. Most published work on silica waveguides refers to two technologies: the $\mathrm{Si} / \mathrm{SiO}_{2} / \mathrm{Si}_{3} \mathrm{~N}_{4} / \mathrm{SiO}_{2}$ and the $\mathrm{Si} / \mathrm{SiO}_{2} /$ doped $\mathrm{SiO}_{2} / \mathrm{SiO}_{2}$ multilayer waveguides [1-2]. Whereas the silica waveguides with $\mathrm{Si}_{3} \mathrm{~N}_{4}$ as guiding layer have large refractive index contrast $(\sim 0.5)$ and are suitable for matching to semiconductor lasers, waveguides with doped $\mathrm{SiO}_{2}$ as guiding layer have small index contrast $\left(\sim 5 \times 10^{-3}\right)$ and are suitable for matching to optical fibres.

We propose a PE-CVD-based technology which uses only $\mathrm{N}_{2} \mathrm{O}$ and $\mathrm{SiH}_{4}$ to form the $\mathrm{SiO}_{2}$ guiding layer. The refractive index profile of the guiding layer is controlled by the $\mathrm{SiH}_{4}$ flow rate during deposition. There are two advantages in using this technique. First, the use of poisonous gas such as $\mathrm{PH}_{3}$ and $\mathrm{GeH}_{4}$ for the doping of the $\mathrm{SiO}_{2}$ is avoided in the entire process. The process is therefore very safe even with simple equipment.* Secondly, the refractive index contrast in using this technology can be varied from $5 \times 10^{-3}$ to 0.5 . The waveguide design is therefore very flexible to meeting differen requirements for the refractive index and optical field profiles.

Waveguide fabrication and loss measurements: $\mathrm{SiO}_{2}$ can be formed with plasma enhanced chemical vapour deposition (PECVD) using the following chemical reaction

$$
\mathrm{SiH}_{4}+2 \mathrm{~N}_{2} \mathrm{O} \stackrel{\text { plasma }}{\longrightarrow} \mathrm{SiO}_{2} \downarrow+2 \mathrm{~N}_{2} \uparrow+2 \mathrm{H}_{2} \uparrow
$$

It is found that by controlling the flow ratio of $\mathrm{SiH}_{4}$ and $\mathrm{N}_{2} \mathrm{O}$ in the PECVD the structure of the deposited $\mathrm{SiO}_{2}$ layer can be changed to $\mathrm{SiO}_{x}$. This change will affect the refractive index of the deposited layer. The change of the refractive index is proportional to the $\mathrm{SiH}_{4} / \mathrm{N}_{2} \mathrm{O}$ flow ratio.

Fig. 1 shows the dependence of the refractive index of the deposited layers on the ratio $\mathrm{SiH}_{4} / \mathrm{N}_{2} \mathrm{O}$ as measured with an

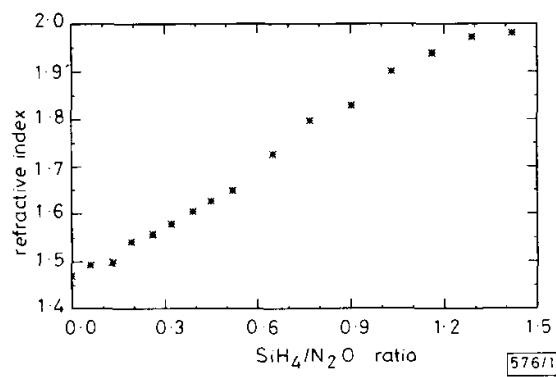

Fig. 1 Refractive index deviation of deposited layer against $\mathrm{SiH}_{4} / \mathrm{N}_{2} \mathrm{O}$ flow ratio in $P E C V D$

Pressure $=360 \mathrm{mtorr}$, power $=25 \mathrm{~W}$ and substrate temperature $=$ $300^{\circ} \mathrm{C}$

Editor's note: This is not so. There are hazards in the use of silane, which is therefore heavily regulated. ellipsometer at a wavelength of $0.6328 \mu \mathrm{m}$. A refractive index of $n=1.46$ is achieved for ratios $\mathrm{SiH}_{4} / \mathrm{N}_{2} \mathrm{O}<0.025$. From the Figure it is seen that the refractive index of the deposited layers varies linearly with the $\mathrm{SiH}_{4}$ flow.

Silica waveguides based on this technology were fabricated as follows. First, a $9 \mu \mathrm{m}$ thick $\mathrm{SiO}_{2}$ is obtained by thermal oxidation of the $\mathrm{Si}$ substrate. The guiding layer is then formed by depositing an $\mathrm{SiO}_{x}$ layer with PECVD. The core ribs are formed by wet etching the guiding layer with BHF at room temperature. Finally, the processed wafer is covered with a PECVD $\mathrm{SiO}_{2}$ layer. The inset of Fig. 3 shows a cross-section of the waveguide structure.

The etch rate of the deposited $\mathrm{SiO}_{x}$ layer with $\mathrm{BHF}$ is dependent on its composition. Fig. 2 shows the dependence of the etching rate from the $\mathrm{SiH}_{4} / \mathrm{N}_{2} \mathrm{O}$ flow ratio. It is seen that oxygen content reduces the etch rate.

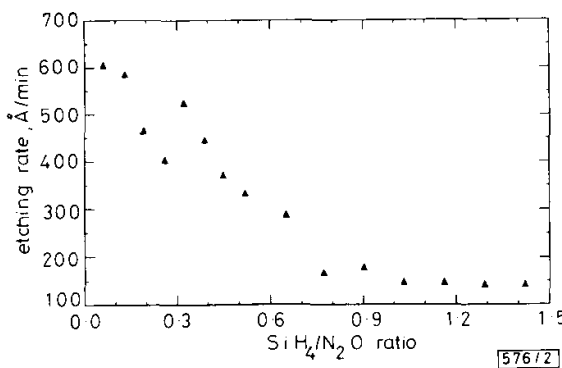

Fig. 2 Etch rate of deposited layer in $B F H$ at room temperature against $\mathrm{SiH}_{4} / \mathrm{N}_{2} \mathrm{O}$ flow ratio

The propagation losses of the waveguides were measured by the cut-back method. The light beam from a $1.3 \mu \mathrm{m}$ semiconductor laser was coupled into the front facets of the waveguides by means of a $\times 20 / 0.45$ microscope objective. The losses of the waveguides were determined by measuring the light intensities at the output facets of the waveguides. The measured propagation losses of the waveguides are of the order of $0.2 \mathrm{~dB} / \mathrm{cm}$. Because optical absorption associated with $\mathrm{OH}^{-}$in the deposited layers contributes to the loss, it can be reduced by annealing the waveguides at a high temperature. After annealing at a temperature of $1100^{\circ} \mathrm{C}$ for $30 \mathrm{~min}$ in an $\mathrm{N}_{2}$ atmosphere, the propagation losses are reduced to $<0 \cdot 1 \mathrm{~dB} / \mathrm{cm}$. The propagation losses of the waveguides after $30 \mathrm{~min}$ annealing at different temperature are shown in Fig. 3.

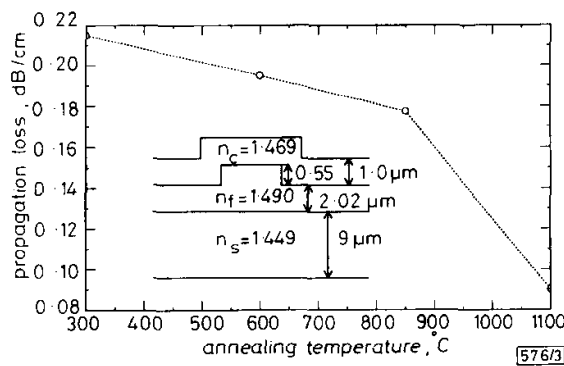

Fig. 3 Propagation losses of waveguides against annealing temperature at wavelength of $1.3 \mu \mathrm{m}, T E$ mode

Conclusions: The technology for fabrication of silica waveguides presented in this Letter is simple and reproducible. Use of poisonous gases is avoided. Waveguides with propagation losses less than $0 \cdot 1 \mathrm{~dB} / \mathrm{cm}$ are obtained. By controlling the flow ratio of $\mathrm{SiH}_{4} / \mathrm{N}_{2} \mathrm{O}$ in the PECVD, the refractive index contrast can be varied between $5 \times 10^{-3}$ and 0.5 , so that the waveguides can be designed to match to either optical fibres or photonic devices based on III-V compound semiconductors.

31st March 1992

Q. Lai, J. S. Gu, M. K. Smit, J. Schmid and H. Melchior (Institute of Quantum Electronics, Swiss Federal Institute of Technology Zurich, CH-8093 Zurich, Switzerland)

ELECTRONICS LETTERS 21st MaY 1992 Vol. 28 No. 11 


\section{References}

1 KAWACHI, M.: 'Silica-based planar lightwave circuit technologies'. Proc. 17th European Conf. on Optical Communication, 8th Int. Conf. on Integrated Optics and Optical Fibre Communication, September 1991, pp. 51-58

2 VAletTe, S., RENARD, S., Denis, H., JADOT, J. P., FOURNiER, A., PHILIPPE, P., GiDON, P., GROUILLET, A. M., and DESGRANGES, D.: 'Si-based integrated optics technologies', Solid State Technol., February 1989 , pp. $69-74$

3 HENRY, C. H. BLONDER, G. F, and KAZARINOV, R. F.: 'Glass waveguides on silicon for hybrid optical packaging', $J$. Lightwave Technol., 1989, LT-7, (10), pp. 1550-1539

4 Sasayama, K., OKUNo, M., and habara, K.: "Coherent optical transversal filter using silica-based waveguides for high-speed signal processing', J. Lightwave Technol., 1991, LT-9, (10), pp. 1225-1230

5 TAKahashl, H., OHMORI, Y., and KAWACHI, M.: 'Design and fabrication of silica-based integrated-optic $1 \times 128$ power splitter', Electron. Lett., 1991, 27, (23), pp. 2131-2133

6 HENRY, C. H., KAZARINOV, R. F., SHANI, Y., KISTLER, R. C., POL, V., and ORLOWSKY, K. J.: 'Four-channel wavelength division multiplexers and bandpass filters based on elliptical Bragg reflectors', J. Lightwave Technol., 1990, LT-8, (5), pp. 748-755

7 SHANI, Y., HENRY, C. H., KISTLER, R. C., KAZARINOV, R. F., and ORLOWSKY, $\mathbf{K}$. J.: 'Integrated optic adiabatic devices on silicon', IEEE J. Quantum Electron, 1991, QE-27, (3), pp. 556-566

\section{VERY HIGH \\ SIDEMODE-SUPPRESSION-RATIO DISTRIBUTED-BRAGG-REFLECTOR LASERS GROWN BY CHEMICAL BEAM EPITAXY}

F. S. Choa, W. T. Tsang, R. A. Logan, R. P. Gnall, U. Koren, T. L. Koch, C. A. Burrus, M. C. Wu, Y. K. Chen, P. F. Sciortino, A. M. Sergent and P. J. Corvini

Indexing terms: Lasers, Semiconductor laser

The fabrication and performance of InGaAs/InGaAsP multiquantum well distributed-Bragg-reflector lasers grown by chemical beam epitaxy are reported. Use of a long and weak grating, which was made on a thin and uniformly grown quaternary layer, has enabled the grating coupling constant $x$ to be well controlled. For most of the laser $\kappa$ to be well controlled. For most of the lasers the measured linewidths are below $10 \mathrm{MHz}$. A record high sidemode sup-

Tunable distributed-Bragg-reflector (DBR) lasers [1-3] are key elements for both a coherent and an incoherent wavelength-division-multiplexed (WDM) communication system. The laser can be used as a transmitter, a local oscillator [4], and even an active filter [5]. Recently, it has also been considered as an ideal laser source for amplitude-shiftkeying (ASK) transmission [6] owing to its high sidemode suppression ratio (SMSR) compared with the unpredictable performance of that of a distributed-feedback (DFB) laser. To increase the threshold gain difference between the main mode and sidemodes of a DBR laser, we can reduce the Bragg reflection bandwidth of the laser by using a weak and long waveguide grating and increase the longitudinal mode spacing by reducing the equivalent cavity length. In either case, the key parameter that needs to be well controlled is the grating coupling constant $\kappa$ which is also a very important parameter in making analogue DFB lasers for CATV applications.

Recently we have succeeded in preparing 1.3 and $1.55 \mu \mathrm{m}$ wavelength multiquantum well (MQW) Fabry-Perot $[7,8]$ distributed-feedback (DFB) [9], and gain coupled DFB [10] lasers by chemical beam epitaxy (CBE) [11] and found very good crystal growth uniformity across 2 inch wafers. Taking the growth advantages of uniformity and well controlled thickness by CBE, we report the fabrication of DBR lasers with a record high SMSR of $58.5 \mathrm{~dB}$.
The CBE system used is a modified Riber CBE 32 system. It can be used to grow very uniform thickness layers across the whole two inch wafer. The growth layer structure of the DBR laser is shown in Fig. 1. After the growth of a $6000 \AA$ thick

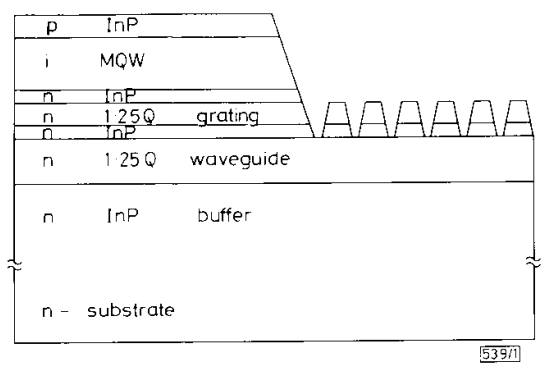

Fig. 1 Growth layer structure of DBR laser

InP buffer layer, a $1.25 \mu \mathrm{m}$ wavelength InGaAsP (1.25 Q) waveguide layer with $2700 \AA$ thickness is grown. Following growth of a thin InP etch stop layer, a $250 \AA$ thick $1.25 \mathrm{Q}$ grating layer and another InP etch stop layer are grown. The multiquantum well (MQW) gain medium is composed of six $50 \AA$ thick InGaAs strained quantum wells and six $120 \AA 1.25$ $\mathrm{Q}$ barriers. Finally, a p-type InP protection layer is grown as the top layer.

The grown wafer is processed by a wet etching technique to remove the gain medium in the passive side. A holographic grating pattern is then generated and transferred to the grating layer through selective etching. Because the thickness of the grating layer is well controlled by the CBE growth time, the grating coupling constant $\kappa$ is also well defined. Followed by stripe etching and semi-insulating and p-cap layer regrowths, the wafer is further processed for multi-electrode metallisation. The lasers are cleaved with a gain section $\sim 225 \mu \mathrm{m}$ long and a grating section $\sim 360 \mu \mathrm{m}$ long.

The fabricated lasers have thresholds of $\sim 20 \mathrm{~mA}$. The tuning range is $21 \AA$. The short tuning range may partly be caused by a reduction of current tuning effect caused by the 'counter wavelength shift' by heat generation in such a long grating section. However, each laser can be easily tuned to its Bragg band centre to obtain better mode behaviour. Fig. 2

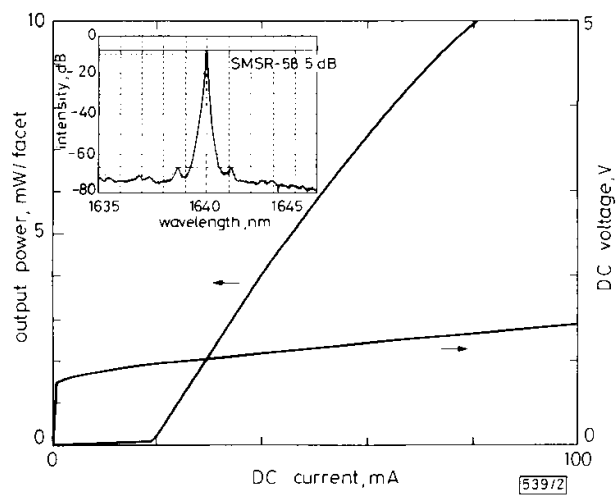

Fig. $2 L-I$ and $I-V$ curves of one of the DBR lasers Inset: output spectrum of laser at $87 \mathrm{~mA}$ bias $l_{\text {active }}=225 \mu \mathrm{m}$ $l_{\text {grating }}=360 \mu \mathrm{m}$

shows the $\mathrm{CW}$ biased light-current (L-I) curve and currentvoltage (I-V) curve of a laser and its SMSR at a bias of $87 \mathrm{~mA}$. A record high SMSR of $58.5 \mathrm{~dB}$ has been achieved with these lasers. For most of the lasers, $10 \mathrm{~mW}$ output can be easily achieved and the measured output linewidths are below $10 \mathrm{MHz}$ which is attributed to the effect of the narrow Bragg bandwidth produced by the long and weak waveguide grating. The theoretically calculated $\kappa$ of the laser structure employing 